\title{
Origin of upper mantle eclogites from the Catoca pipe (N.-E. Angola)
}

\author{
N.M. Korolev ${ }^{1,2}$, L.P. Nikitina ${ }^{2,3}$, A.E. Melnik ${ }^{4,2}$, V.N. Zinchenko ${ }^{5}$ \\ ${ }^{1}$ University of British Columbia, Vancouver, BC, Canada, nkorolev@eoas.ubc.ca \\ ${ }^{2}$ Institute of Precambrian Geology and Geochronology RAS, St. Petersburg, Russia \\ ${ }^{3}$ St. Petersburg State University, St. Petersburg, Russia, Ipnikitina2011@yandex.ru \\ ${ }^{4}$ Saint-Petersburg Mining University, St. Petersburg, Russia, aleks@melnik.co \\ ${ }^{5}$ Geological Department of SM Catoca, Catoca, Angola, vladimir.zin@mail.ru
}

The abstract studies mineralogical, petrological and geochemical evidences on genesis and alteration of mantle eclogites xenolths (21 samples) from Catoca kimberlite pipe (Kasai Craton, N.-E. Angola). Three types of eclogite have been distinguished: high-alumina (high- $\mathrm{Al}_{2} \mathrm{O}_{3}$ ), low-magnesian (low$\mathrm{MgO}$ ) and high-magnesian (high-MgO) eclogites. Eclogites of each group are characterized by its own unique set of features. High- $\mathrm{Al}_{2} \mathrm{O}_{3}$ eclogites consist of high-Na omphacite (Jd 51-67) and garnet (Prp30-33 Alm28-29 Grs37-41). There are small quantities of kyanite in each sample (up to 15 vol.\%). Low-MgO eclogites are bimineralic, composition of garnet: Prp35-53 Alm28-45 Grs16-28; composition of omphacite: Jd 32-57. High-MgO eclogites are also bimineralic and consist of minerals with a high MgO content, composition of garnet: Prp68-70 Alm21-23 Grs5-8; composition of omphacite: Jd 19-25. Rutile is the most common accessory mineral. High- $\mathrm{Al}_{2} \mathrm{O}_{3}$ and low-MgO eclogites have a granoblastic texture. High-MgO eclogites have mainly porphyroblastic-like texture combined with either banded or implicitly shale and massive structure.

We used almost all known tools of classical thermobarometry to estimate the PT-parameters of mantle eclogites. In the case of low-MgO some of high- $\mathrm{Al}_{2} \mathrm{O}_{3}$ eclogites geothermometers (Ellis, Green, 1979; Powell, 1985; Ai, 1994; Krogh, 2000; Nakamura, 2006, 2009) have shown a good agreement in the range of $1000-1200^{\circ} \mathrm{C}$ at pressures of $40-50$ kbar. PT-parameters of high- $\mathrm{Al}_{2} \mathrm{O}_{3}$ and high-MgO eclogites vary in the significant range $900-1360^{\circ} \mathrm{C}, 35-60 \mathrm{kbar}$. Thus, to compare all samples together we have choosen the same for all groups of eclogites set of tools. The equilibration temperatures of the eclogite xenoliths were evaluated using a garnet-clinopyroxene geothermometer (Nakamura, 2006). To calculate the pressure of the xenoliths, a geotherm with the heat flow capacity of $40 \mathrm{~mW} / \mathrm{m}^{2}$ was chosen (Hasterok, Chapman, 2011). The relevance of the selection is based on the indirect mineralogical and geochemical criteria ( $\mathrm{Mg \#}$ and $\mathrm{Mg} / \mathrm{Si}$ in the reconstracted bulk rock, Cr contents in rock-forming minerals). The choice of the geotherm accounted for the fact that almost all of the current estimates of $\mathrm{P}$ and $\mathrm{T}$ parameters for the mantle beneath ancient Archaean cratons (including Kasai Craton) are close to it. In addition, the Catoca unaltered garnet lherzolite xenolith points lie on the geotherm with the heat flow capacity of $40 \mathrm{~mW} / \mathrm{m}^{2}$.

Different groups of the eclogites represent different levels (with insignificant overlaps) of the Kasai Craton lithospheric mantle. The upper part of the mantle profile $110-170 \mathrm{~km}(\mathrm{P}=35-50 \mathrm{~kb}, \mathrm{~T}=900$ $1200^{\circ} \mathrm{C}$ ) is represented by high- $\mathrm{Al}_{2} \mathrm{O}_{3}$ and low-MgO eclogites. High-MgO eclogites were taken from depths corresponding to an area of diamond stability: $170-210 \mathrm{~km}, \mathrm{P}=52-60 \mathrm{~kb}, \mathrm{~T}=1220-1360^{\circ} \mathrm{C}$. The lower boundary of the lithospheric mantle beneath the Kasai Craton according to global seismic tomography is estimated at the depth of 300-400km (O’Reilly et al., 2009; Begg et al., 2009). Thus, our data shows that mantle eclogites from the Catoca pipe represent only about 2/3-1/2 of the lithospheric mantle (110-210 km).

\section{Origin of mantle eclogites, geochemical evidences.}

High- $\mathrm{Al}_{2} \mathrm{O}_{3}$ eclogites. $\mathrm{REE}_{\mathrm{N}}$ patterns (Fig. 1), $\mathrm{Y}, \mathrm{Zr}$, Li contents and $\mathrm{Zr} / \mathrm{Sm}, \mathrm{Zr} / \mathrm{Hf}, \mathrm{La} / \mathrm{Sm}$ ratios (Fig. $2 \mathrm{~b})$ and other geochemical markers of reconstructed whole rock of high- $\mathrm{Al}_{2} \mathrm{O}_{3}$ eclogites reveal greatest similarity with ophiolitic gabbro and modern oceanic gabbro. Weak Eu-peak together with an increased concentration of $\mathrm{Sr}$ in garnets are also an indicator of a plagioclase-bearing protolith. 


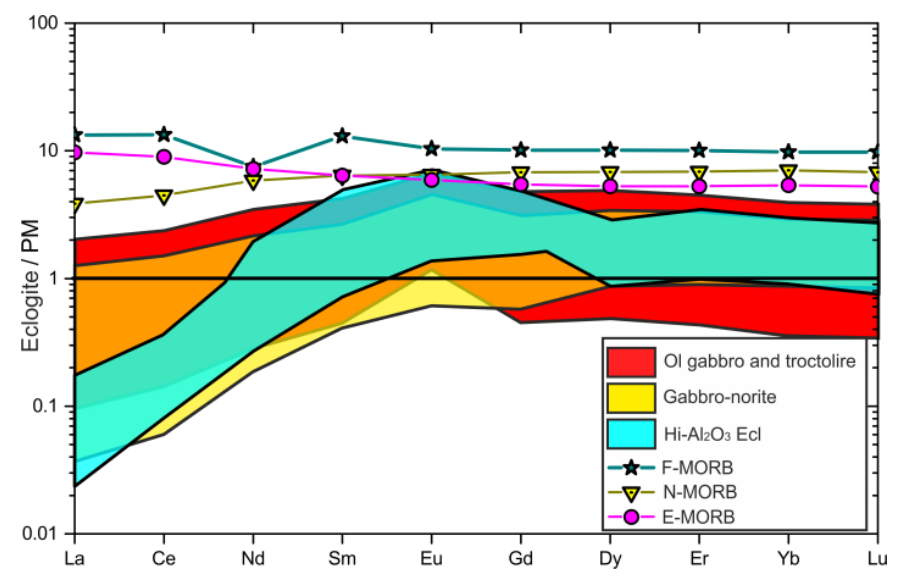

Fig. 1. Rare Earth element patterns of the reconstructed bulk composition of high- $\mathrm{Al}_{2} \mathrm{O}_{3}$ eclogites and hypothetical protolith (gabbro and troctolite, gabbro-norite, F-MORB, N-MORB, E-MORB).

Low-MgO eclogites. $\mathrm{REE}_{\mathrm{N}}$ patterns, $\mathrm{Y}$, $\mathrm{Zr}$, Li contents, $\mathrm{Zr} / \mathrm{Sm}, \mathrm{Zr} / \mathrm{Hf}, \mathrm{La} / \mathrm{Sm}$ ratios as well as other geochemical markers and depleted $\mathrm{LREE}_{\mathrm{N}}$ of the reconstructed whole rock of lo-MgO eclogites may indicate that these eclogites were formed during transformation of N-MORB (possible with a boninite component) restite. The geochemical modelling results of melting at $1100-1200^{\circ} \mathrm{C}, 30-40 \mathrm{kbar}$ support the introduced assumption. According with the geochemical modelling results a melting degree of eclogitic protolith/eclogites could reach $25-50 \%$. Figure 2 demonstrates the similarity of the compositions of restites and mantle eclogites in relation to key indicators $\mathrm{Zr} / \mathrm{Sm}, \mathrm{Zr} / \mathrm{Hf}, \mathrm{La} / \mathrm{Lu}$.
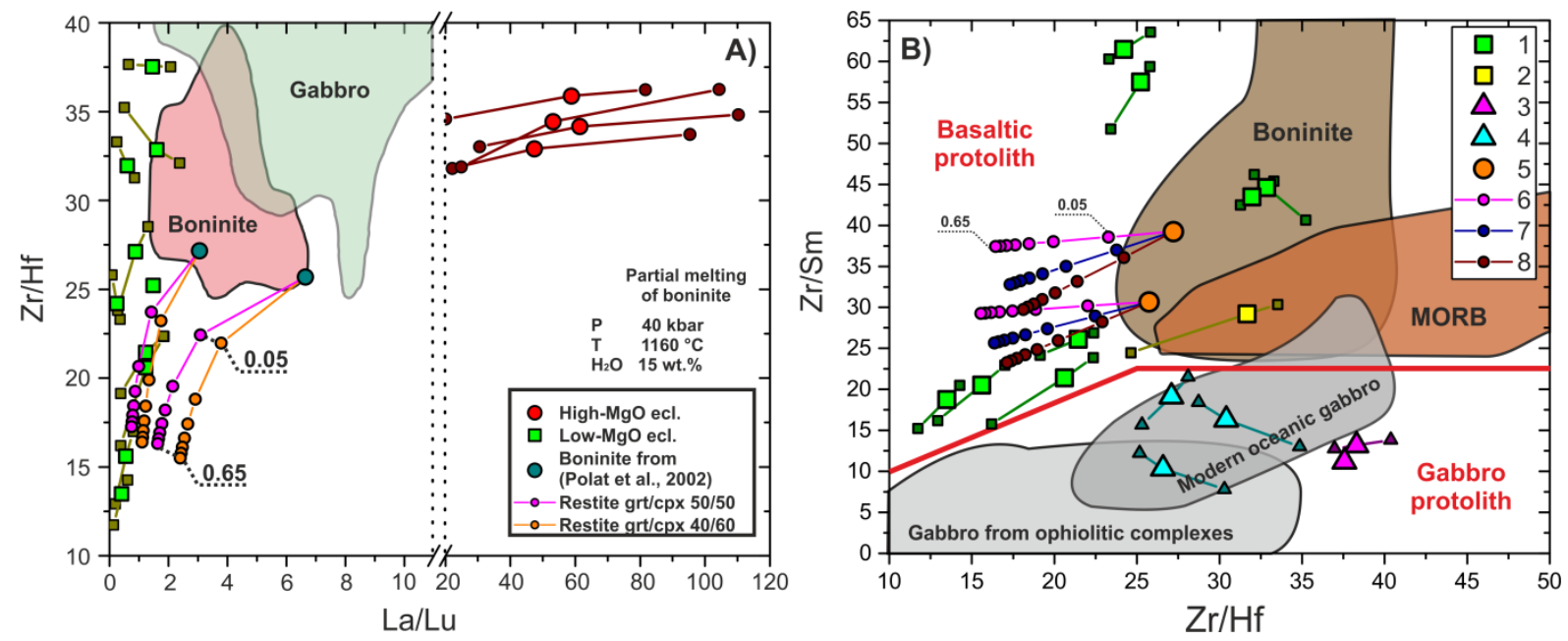

Fig. 2. A) The $\mathrm{Zr} / \mathrm{Hf}$ vs. La/Lu diagram for the reconstructed bulk compositions of mantle eclogites. Signs on the trend of partial melting of boninites (orange and purple lines) indicates restit. The degree of partial melting increases from 0.05 to 0.65 in increments of 0.1 . B) The $\mathrm{Zr} / \mathrm{Sm}$ vs. $\mathrm{Zr} / \mathrm{Hf}$ diagram for the reconstructed bulk compositions of mantle eclogites. 1 - Low-MgO eclogites, 2 - altered low-MgO eclogite, 3 and $4-\mathrm{High}_{-} \mathrm{Al}_{2} \mathrm{O}_{3}$ eclogites, 5 - boninites, 6-8 - Trends of partial melting of boninites (6 - 40grt/60cpx, 7 - 50grt/50cpx, 8 60 grt/40cpx) with the degree of partial melting from 0.05 to 0.65 .

Values of ${ }^{187} \mathrm{Sr} /{ }^{186} \mathrm{Sr}(0.7056-0.7071, \mathrm{n}=4)$, positive $\varepsilon_{\mathrm{Nd}}(1.8-2.6, \mathrm{n}=9)$, high values of ${ }^{187} \mathrm{Re} /{ }^{188} \mathrm{Os}(80$ and 135) and ${ }^{187} \mathrm{Os} /{ }^{188} \mathrm{Os}$ (1.311 and 1.9709), high radiogenic ${ }^{187}$ Os isotopic composition ( $\gamma \mathrm{Os}=129$ and 147) in single eclogites support their subduction origin.

High-MgO eclogites. A large body of mineralogical and geochemical data shows that at least part of high-MgO eclogites could be recrystallized at mantle conditions. Clinopyroxene and garnet from high-MgO eclogites are enriched in Ba, Sr, LREE and other trace elements relative to the counterpart minerals from a peridotite and other eclogite types from the Catoca pipe. Some samples contain fine grained garnet as well as rare coarse grains $(\sim 5 \mathrm{~mm})$. Proto-cores were found in some coarse grains. Chemical composition of the proto-core garnet (major and trace elements) appreciably differs from the recrystallized fine grained garnet. Comparison of the different garnet composition (unaltered and 
altered garnet from low-MgO eclogite, proto-cores and recrystallized fine grained garnet from high$\mathrm{MgO}$ eclogite and unaltered garnet from fresh peridotite xenolith) is shown in the figure 3.

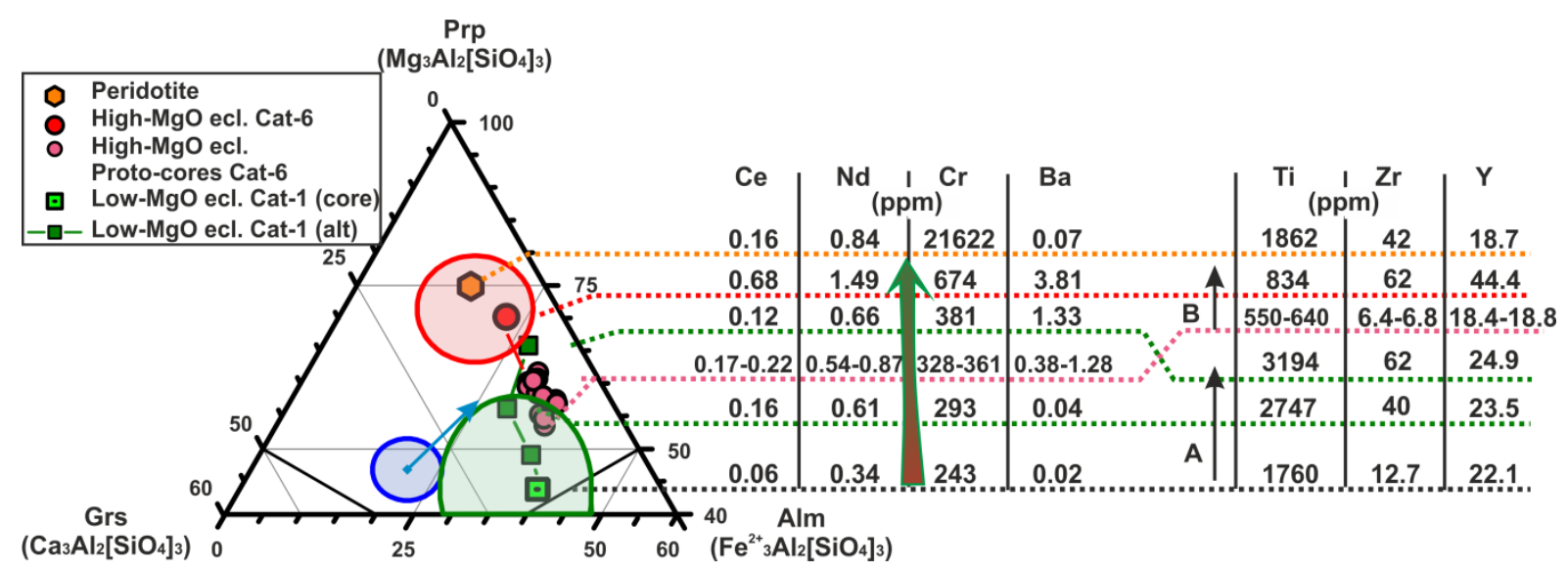

Fig. 3. Comparison of chemical composition of garnet proto-cores from high-MgO eclogite with differen type of garnet from mantle xenoliths from Catoca pipe. Red area shows compositions of garnets from high-MgO eclogites and peridotite; Green area shows compositions of garnets from low-MgO eclogites; Blue area shows the composition of garnets from high- $\mathrm{Al}_{2} \mathrm{O}_{3}$ eclogites.

As shown by our study, processes of recrystallization of the mantle eclogites and specific "metasomatic" processes leading to a high-niobium rutile formation have already appeared. The average $\mathrm{Nb}_{2} \mathrm{O}_{5}$ content 7-11 wt.\% in the rutiles from the high-MgO eclogites was determined. There are some areas (no more than 10-15 microns) with composition of $\mathrm{Nb}_{2} \mathrm{O}_{5}$ up to 20-25 wt.\% and $\mathrm{Ta}_{2} \mathrm{O}_{5}$ up to 4 wt.\% within the rims of the rutile grains (Korolev et al., 2014).

The reported study was funded by the Russian Foundation of Basic Research (RFBR), research projects № 16-35-00321 mol_a and 16-35-60092 mol_a_dk.

\section{References}

Ai Y (1994) A revision of the garnet-clinopyroxene Fe+2-Mg exchange geothermometer. Contrib Mineral Petrol 115:467-473

Begg GC, Griffin WL, Natapov LM, O’Reilly SY, Grand SP, O’Neill CJ, Hron-sky JMA, Poudium Djomani Y., Swain CL, Deen T, Bowden P (2009) Thelithospheric architecture of Africa: tomography, mantle petrology and tectonicevolution. Geosphere 5:23-50

Ellis DJ, Green DH (1979) An Experimental Study of the Effect of Ca Upon Garnet-Clinopyroxene Fe-Mg Exchange Equilibria. Contrib Mineral Petrol 71:13-22

Hasterok D, Chapman DS (2011) Heat production and geotherms for the continen-tal lithosphere. Earth Planet Sci Lett 307:59-70

Korolev NM, Marin YB, Nikitina LP, Zinchenko VN, Chissupa HM (2014) High-Nb rutile from upper mantle eclogite xenoliths of the diamond-bearing kimberlite pipe Catoca (Angola). Dokl Earth Sci 454(1):50-53

Krogh Ravna EJ (2000) The garnet-clinopyroxene Fe2+-Mg geothermometer: an updated calibration. J Metamorph Geol 18(2):211-219

Nakamura D (2009) A new formulation of garnet-clinopyroxene geothermometer based on accumulation and statistical analysis of a large experimental data set. J Metamorph Geol 27:495508

O’Reilly SY, Zhang M, Griffin WL, Begg G, Hronsky J (2009) Ultradeep continental roots and their oceanic remnants: a solution to the geochemical "mantle reservoir" problem? Lithos 112(Suppl 2):1043-1054.

Powell R (1985) Regression diagnostics and robust regress in geothermometer/geobarometer calibration: the garnet-clinopyroxene geothermometer revisited. J Metamorph Geol 3(3):231-243 